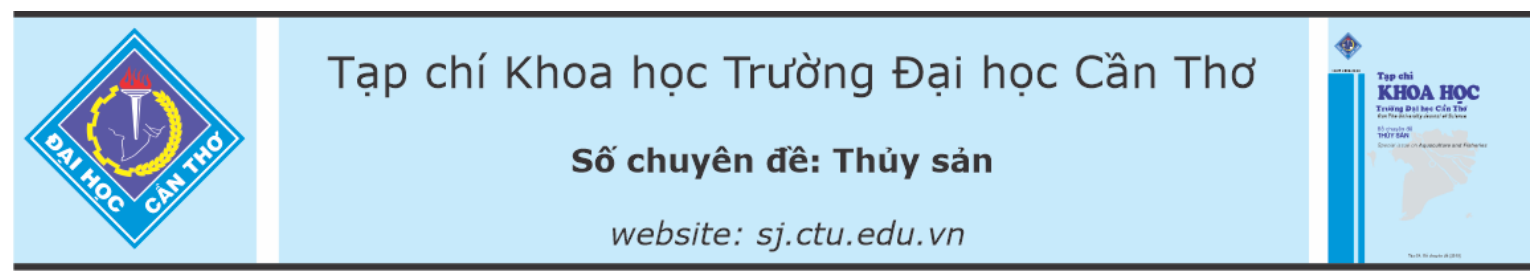

DOI:10.22144/ctu.jvn.2021.064

\title{
ĐẶC ĐIỂM DINH DỮ̛̃NG CỦA CÁ SỦU RĂNG NHỎ Panna microdon (Bleeker, 1849) Ở ĐỒNG BẰNG SÔNG CỦU LONG
}

\author{
Nguyễn Thị Vàng ${ }^{1 *}$, Nguyễn Văn Mừng ${ }^{2}$, Trương Hoàng Dinh ${ }^{2}$ và Trần Đắc Định ${ }^{1}$ \\ ${ }^{1}$ Khoa Thủy sản, Truờng Đại học Cần Tho \\ ${ }^{2}$ Sinh viên ngành Quản lý nguồn lợi thủy sản K42, Khoa Thủy sản, Truòng Đại học Cần Tho \\ *Nguời chịu trách nhiệm về bài viết: Nguyễn Thị Vàng (email: ntvang@ctu.edu.vn)
}

\section{Thông tin chung:}

Ngày nhận bài: 22/02/2021

Ngày nhận bài sủa: 28/04/2021

Ngày duyệt đăng: 01/06/2021

\section{Title:}

Nutritional characteristics of

Panna microdon (Bleeker,

1849) in the Mekong Delta

\section{Tù khóa:}

Cá si̛u răng nhỏ, đặc điểm dinh dương, Đồng bằng sông

Cưu Long, Panna microdon

\section{Keywords:}

Characteristics, Mekong Delta, nutritional, Panna microdon

\begin{abstract}
Panna microdon, one of the economic species in the Mekong Delta, has high meat quality and is usually consumed as fresh or dried products. Study on the feeding biology of P. microdon was carried out from June 2019 to April 2020 in the coastal areas of Soc Trang and Ca Mau provinces. Samples in various sizes were collected using trawl net. The results show that P. microdon possesses characteristics of carnivorous species with terminal large mouth bearing with canine teeth, short and sparse gill rakers, short esophagus with thick wall, pyloric cecum formed by 3-8 appendices, relative short intestine in $S$-shape. The relative short gut (relative length of gut $-R L G<1$ ) suggests that they are carnivorous, as evidenced by food composition mainly from fishes, shrimps, mantis shrimps, krills, and crabs. Food composition is not significant differences among fish sizes suggesting this species does not change their feeding habit during life stages.
\end{abstract}

\section{TÓM TẮT}

Cá sưu răng nhỏ (Panna microdon) là một trong nhũng loài có giá trị kinh tế cao do thịt ngon, thường được bán tuơi, làm khô. Nghiên cứu đặc điểm dinh duõng của cá sửu răng nhỏ được thực hiện tù tháng 6 năm 2019 đến tháng 4 năm 2020 tại vùng ven biển tỉnh Sóc Trăng và Cà Mau. Mẫu cá với các kích cõ khác nhau được thu bằng luới kéo. Kết quả nghiên cứu cho thấy cá sưu răng nhỏ có miệng rộng, rạch miệng xiên, răng nhọn, lược mang thura và ngắn, thực quản ngắn có vách dày dạng hình ống, da dày hình túi, manh tràng có tù 3 đến 8 ống, ruột ngắn dạng hình chĩ $S$. Chỉ số sinh trắc ruột $-R L G<1$ cho thấy cá sưu răng nhỏ có tính ăn động vật. Thành phần thức ăn chủ yếu trong dạ dày của cá sửu răng nhỏ là cá, tôm, tôm tít, ruốc, cua/ghe và các loại thức ăn khác. Kết quả cũng cho thấy không có sụ thay đổi thành phần thức ăn của cá sửu răng nhỏ ở các kích cõ khác nhau.

\section{GIỚI THIỆU}

Họ cá đù (Sciaenidae) là một trong những họ cá quan trọng trong nghề cá thương mại với nhiều loài có giá trị kinh tế cao (Thong, 2008). Trong họ cá đù, cá sửu răng nhỏ (Panna microdon) là một trong những loài có giá trị kinh tế cao do thịt ngon, thường được bán tươi, làm khô. Chúng được khai thác bằng lưới kéo hoặc câu ở vùng biển ven bờ; trong khi cá 
con thường phân bố trong rừng ngập mặn (Mukherjee et al., 2012). Loài cá này phân bố rộng, từ Tây Thái Bình Dương đến Ấn Độ Dương (Sasaki, 1995; Froese \& Pauly, 2021). Ơ Việt Nam cũng được ghi nhận ở các khu vực cửa sông ven biển Đồng bằng sông Cửu Long (ĐBSCL) (Trần Đắc Định và ctv., 2013). Qua phân tích các kết quả nghiên cứu cho thấy các công trình nghiên cứu trước đây chỉ tập trung về thành phần loài, tuy nhiên cũng còn hạn chế ở một số khu vực. Đặc biệt đối với loài cá sửu răng nhỏ, tác giả chưa tìm thấy công trình nghiên cứu nào nghiên cứu về đặc điểm dinh dưỡng của cá sửu răng nhỏ ở ĐBSCL; trong khi đây là loài có giá trị kinh tế cao, sản lượng khai thác tự nhiên đã suy giảm rất nhiều. Do đó để có cơ sở phục hồi và quản lý nguồn lợi cá đù nói chung và loài cá sửu răng nhỏ nói riêng, rất cần thiết có một nghiên cứu về "Đặc điểm dinh dưỡng của cá sửu răng nhỏ Panna microdon (Bleeker, 1849) ở ĐBSCL" nhằm làm cơ sở cho việc phát triển thành đối tượng nuôi trong tương lai.

\section{PHƯƠNG PHÁP NGHIÊN CÚU}

\subsection{Thời gian và địa điểm nghiên cứu}

Nghiên cứu được thực hiện từ tháng 6/2019 đến 4/2020 ở vùng ven biển Đông (Sóc Trăng) và biển Tây (Cà Mau) của ĐBSCL (Hình 1).

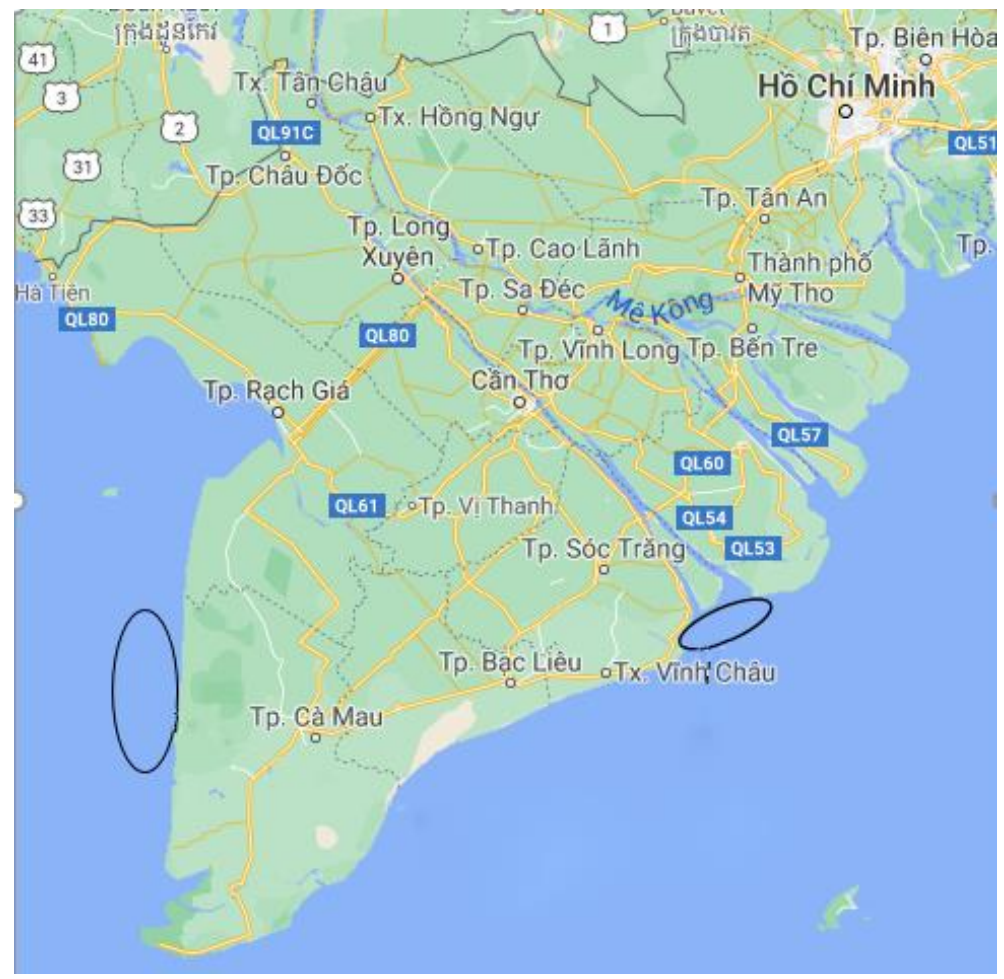

Hình 1. Bản đồ địa điểm thu mẫu (Nguồn: Google map)

Đối tuợng nghiên cưu: Cá sửu răng nhỏ (Panna microdon (Bleeker, 1849)) (Hình 2)

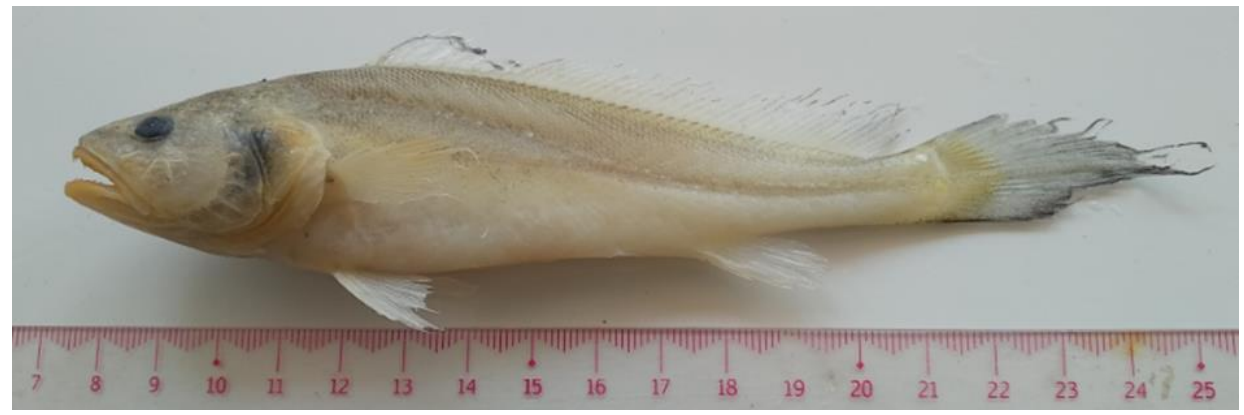

Hình 2. Hình thái bên ngoài cá sửu răng nhỏ 


\subsection{Phương pháp thu và phân tích mẫu}

\subsubsection{Phuoong pháp thu và cố định mẫu}

Mẫu cá được thu trực tiếp bằng lưới kéo có kích thước nhỏ nhất là $1,5 \mathrm{~cm}$ và thu 2 đợt, đợt mùa mưa (tháng 6/2019 kéo dài đến tháng 11/2019) và đợt mùa khô (tháng 12/2019 đến tháng 4/2020). Mẫu được thu với kích cỡ dao động khoảng $4 \mathrm{~cm}$ đến 30 $\mathrm{cm}$ (cỡ mẫu ít nhất là 60 mẫu/đợt) và được cố định ngay trong dung dịch formol $10 \%$.

\subsubsection{Xác định cấu trúc ống tiêu hóa và tính $\breve{a} n$}

Mô tả cấu trúc ống tiêu hóa được thực hiện theo tài liệu của Lagler et al. (1977), Bond (1996) và Nguyễn Bạch Loan (2004). Kích cỡ miệng cá được tính theo công thức của Shirota (1970): $\mathrm{D}=\sqrt{2} * \mathrm{AB}$, với $\mathrm{AB}$ là chiều dài xương hàm trên. Chỉ số $R L G$ được tính theo công thức của Al-Hussainy (1949): $\mathrm{RLG}=$ chiều dài ruột $(\mathrm{Li}) /$ chiều dài tổng $(\mathrm{Lt})$. Theo Nikolsky (1963), những loài cá có tính ăn thiên về động vật sẽ có chỉ số RLG $(\mathrm{Li} / \mathrm{Lt})<1$, cá ăn tạp khi RLG $=1-3$ và cá ăn thực vật khi RLG > 3 .

\subsubsection{Phuoong pháp xác định phổ thức ăn}

Phổ thức ăn được xác định theo phương pháp tần số xuất hiện và phương pháp khối lượng. Phương pháp tần số xuất hiện được tiến hành theo hai bước: i) các loại thức ăn trong mẫu quan sát sẽ được liệt kê và ghi nhận sự hiện diện của chúng trong từng mẫu (dạ dày); ii) số lượng mẫu (dạ dày) trong đó có sự hiện diện của từng loại thức ăn sẽ cộng lại và tính tương tự cho các loại thức ăn còn lại, từ đó xác định tần số xuất hiện theo tỉ lệ phần trăm trên tổng số mẫu quan sát. Phương pháp này cho phép định tính thành phần thức ăn và tần số xuất hiện của mỗi loại thức ăn trong số mẫu quan sát. Phương pháp khối lượng: i) xác định tổng khối lượng thức ăn có trong dạ dày của cá; ii) xác định khối lượng từng loại thức ăn cũng bằng cân điện tử với độ chính xác $0,01 \mathrm{~g}$. Khối lượng của mỗi loại thức ắn được tính thành phần trăm trên tổng khối lượng thức ăn có trong dạ dày. Từ đó phổ thức ăn của cá được xác định bằng cách kết hợp giữa phương pháp tần số xuất hiện và phương pháp khối lượng thức ăn (Phạm Thanh Liêm \& Trần Đắc Định, 2004).

\subsubsection{Phuoong pháp phân tích số liệu}

Thành phần thức ăn tự nhiên trong dạ dày cá được xác định dựa theo các tài liệu của Nguyễn Văn Thường \& Trương Quốc Phú (2009), Tôn Thất Chất \& Nguyễn Văn Chung (2013), Fao (2001) và Trần Đắc Định và ctv. (2013). Giá trị trung bình, độ lệch chuẩn, tần số xuất hiện,... được xác định bằng phần mềm Microsoft Excel 2013.

\section{KẾT QUẢ VÀ THẢO LUẬN}

\section{1. Đặc điểm cấu trúc ống tiêu hóa}

a) Miệng: là cơ quan bắt mồi quan trọng của cá, dựa vào vị trí miệng dự đoán được tính ăn của cá. Ngoài ra, vị trí miệng và kích cỡ giới hạn độ mở miệng để bắt mồi có thể giúp cho cá bắt mồi một cách hiệu quả (Chao \& Musick, 1977). Kết quả quan sát cho thấy cá sửu răng nhỏ có miệng dưới rộng vừa, rạch miệng xiên kéo dài đến giữa hốc mắt theo hướng từ mõm đến mép miệng, xương hàm co duỗi được, đặc điểm này cho thấy đây là loài cá bắt mồi ở tầng đáy (Hình 3). Kết quả phân tích cho thấy kích cỡ miệng cá là $1,89 \pm 0,51 \mathrm{~cm}$. Kết quả này cho thấy cá sửu răng nhỏ có thể bắt được mồi có kích thước nhỏ và phù hợp với cỡ miệng như ruốc, tôm và cá con. So với nghiên cứu loài cá sửu Micropogonias unduiatus có kích cỡ miệng dao động $1,24 \pm 0,49$ và Leiostomus xanthurus $(2,12 \pm 0,24)$ ở vùng ven biển Mexico (Ocana-Luna \& Sanchez-Ramírez, 1998), loài cá sửu răng nhỏ có kích cỡ miệng tương đồng với hai loài cá này.

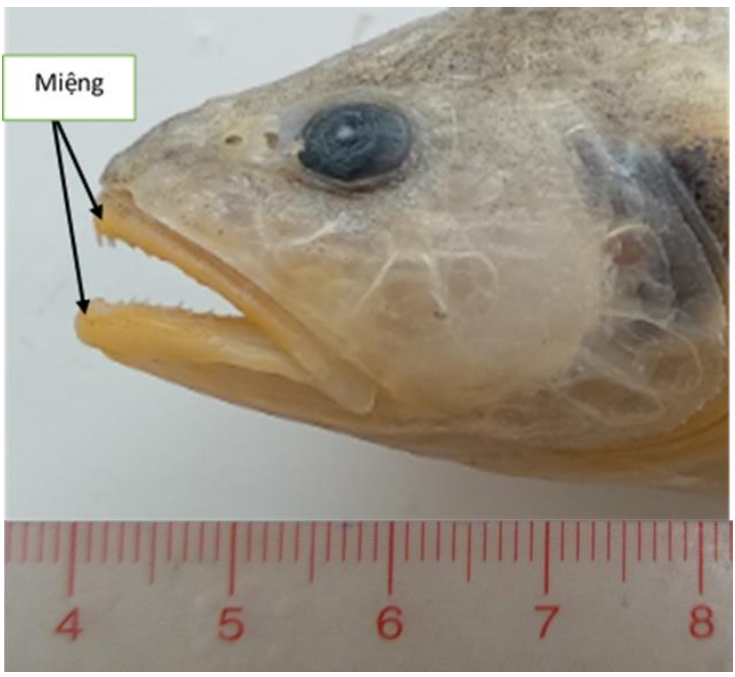

Hình 3. Hình dạng miệng

b) Răng hàm: cá sửu răng nhỏ có chiều dài hàm trên lớn hơn hàm dưới, xương hàm cứng. Răng phân bố ở cả hàm trên và hàm dưới (Hình 4 ). Răng hàm cứng và sắc bén; có $1-2$ cặp răng cửa to và nhọn ở hàm trên chứng tỏ cá sửu răng nhỏ có khả năng bắt và xé mồi, hàm dưới răng xếp thành hình vòng cung có chức năng cắn và giữ chặt con mồi, cá sửu răng nhỏ không có răng nanh và không có cơ nhai. 


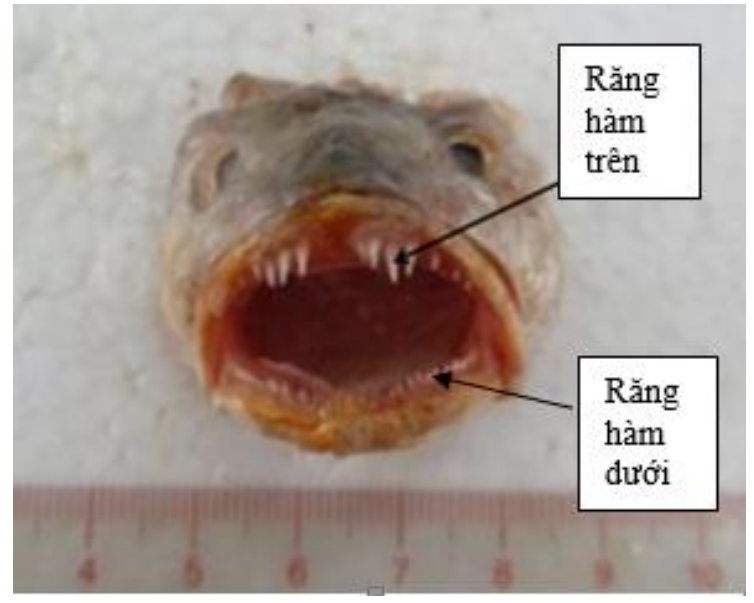

Hình 4. Răng hàm trên và răng hàm dưới

c) Răng hầu: nằm cuối trong xoang miệng, răng hầu phân bố ở cả trên và dưới hầu (Hình 5). Răng hầu có chức năng nghiền thức ăn và vận chuyển thức ăn đến thực quản (Chao \& Maosick, 1977).

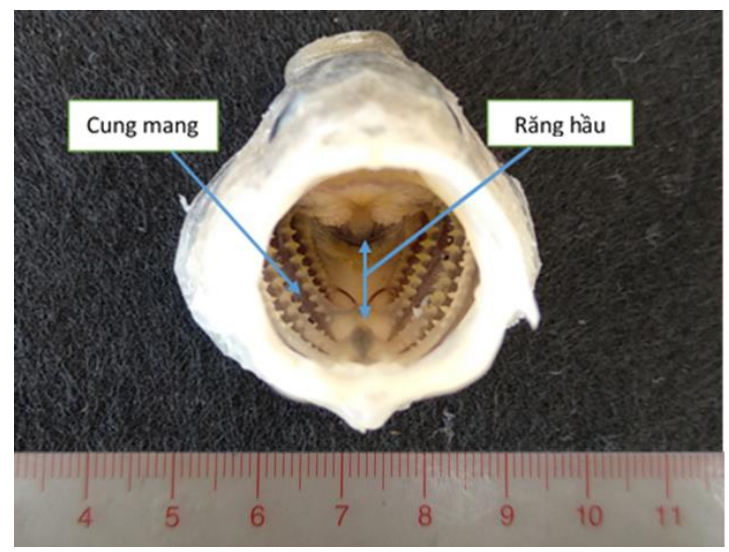

Hình 5. Răng hầu

d) Lược mang: lược mang nằm trong xoang miệng, có chức năng lọc và giữ thức ăn. Chao \& Musick (1977) cho rằng những lược mang trên các cung mang của cá không những có vai trò quan trọng trong việc bảo vệ các tia mang tránh khỏi sự mài mòn bởi thức ăn mà chúng còn có thể thích nghi với thức ăn riêng biệt và tính ăn của chúng. Tác giả cũng cho rằng số lượng, kích thước và hình dạng lược mang ở nhóm cá đù phản ảnh tính ăn của chúng. Lược mang thường nằm phía trên mặt lưng của cung mang và phát triển ở cung mang thứ nhất, mặt trong của cung mang thường là các nốt sần. Kết quả quan sát cho thấy cá sửu răng nhỏ có lược mang màu vàng ngà, thưa và tách rời nhau, gốc các lược mang gắn vào cung mang. Có 4 đôi cung mang và đôi thứ 5 biệt hóa thành hầu. Mỗi cung mang có hai hàng lược mang và hai hàng tia mang, các lược mang nhọn và cứng hướng vào xoang miệng, một hàng lược mang có dạng núm gai và hàng còn lại có các que mang gắn trên cung mang, trên các que mang có các gai nhọn. Trên cung mang có các tia mang mảnh, dài, màu đỏ xếp khích nhau giữ chức năng hô hấp và nằm đối xứng với lược mang. Số lược mang trên cung mang thứ nhất dao động từ 12 đến 15 lược mang (Hình 6).

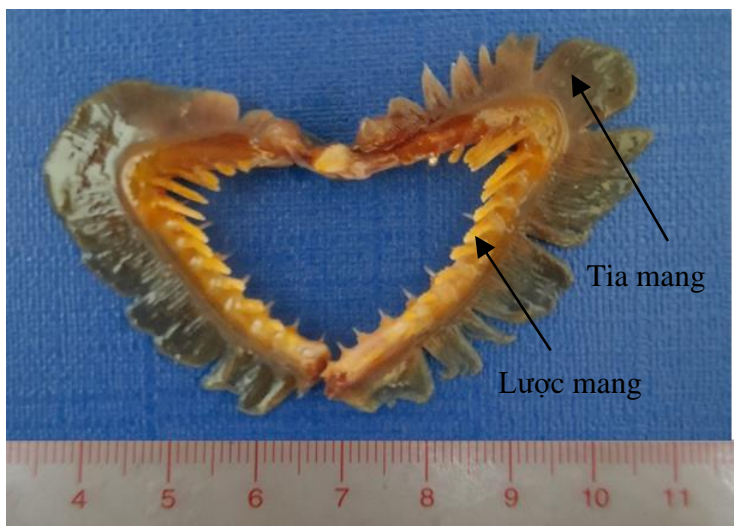

Hình 6. Lược mang trên cung mang thứ nhất

e) Thực quản: nối tiếp sau hầu là thực quản, là nơi thức ăn đi qua và đến dạ dày. Thực quản ngắn có vách dày, hình ống với nhiều nếp gấp.

f) Da dày: dạ dày có dạng hình túi nối tiếp sau thực quản có vách dày, là nơi chứa đựng thức ăn và tiết ra dịch tiêu hóa để tham gia quá trình tiêu hóa thức ăn.

g) Manh tràng: cá sửu răng nhỏ thường có là 3 đến 8 manh tràng, manh tràng có dạng ống với 1 đầu bịt kín và nằm ở vùng tiếp giáp giữa dạ dày và ruột.

d) Ruột: là cơ quan nối giữa dạ dày và hậu môn, ruột ngắn thẳng, xếp gấp khúc chia thành hai đoạn rõ rệt tạo hình chữ $\mathrm{S}$. Đa số các loài thuộc họ Sciaenidae có ruột dạng chũ̃ S (Sasaki, 1989). Kết quả phân tích cho thấy cá sửu răng nhỏ có chiều dài

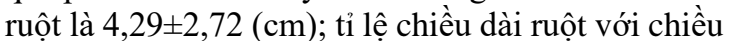
dài thân cá, $R L G=0,32 \pm 0,13$. Kết quả này cho thấy cá sửu răng nhỏ có tính ăn động vật (RLG $<1)$. 


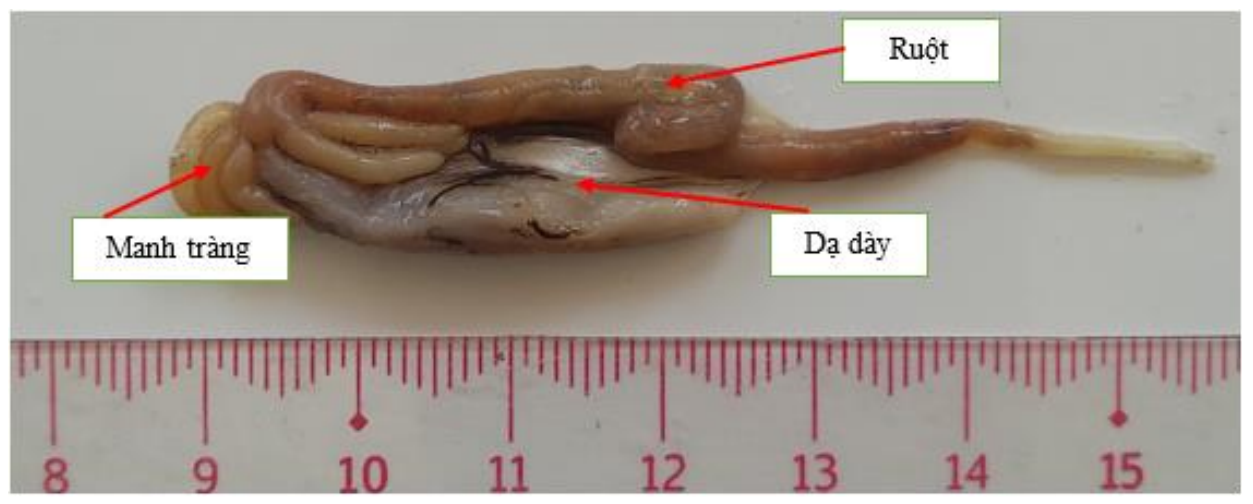

Hình 7: Dạ dày, manh tràng và ruột

\subsection{Phổ thức ăn}

\subsubsection{Phuong pháp tần số xuất hiện}

Kết quả phân tích thức ăn trong dạ dày cá cho thấy thành phần thức ăn của cá sửu răng nhỏ khá đa dạng với hai nhóm chính là nhóm cá và nhóm giáp xác (Hình 8 và Hình 9). Trong đó, nhóm giáp xác xuất hiện nhiều nhất $(92,59 \%)$, cụ thể là ruốc $(47,09 \%)$, tôm $(39,68 \%)$, tôm tít $(4,1 \%)$ và cua/ghẹ $(1,72 \%)$; nhóm cá $(12,96 \%)$ và các loại thức ăn khác $(1,46 \%)$ (Bảng 1).

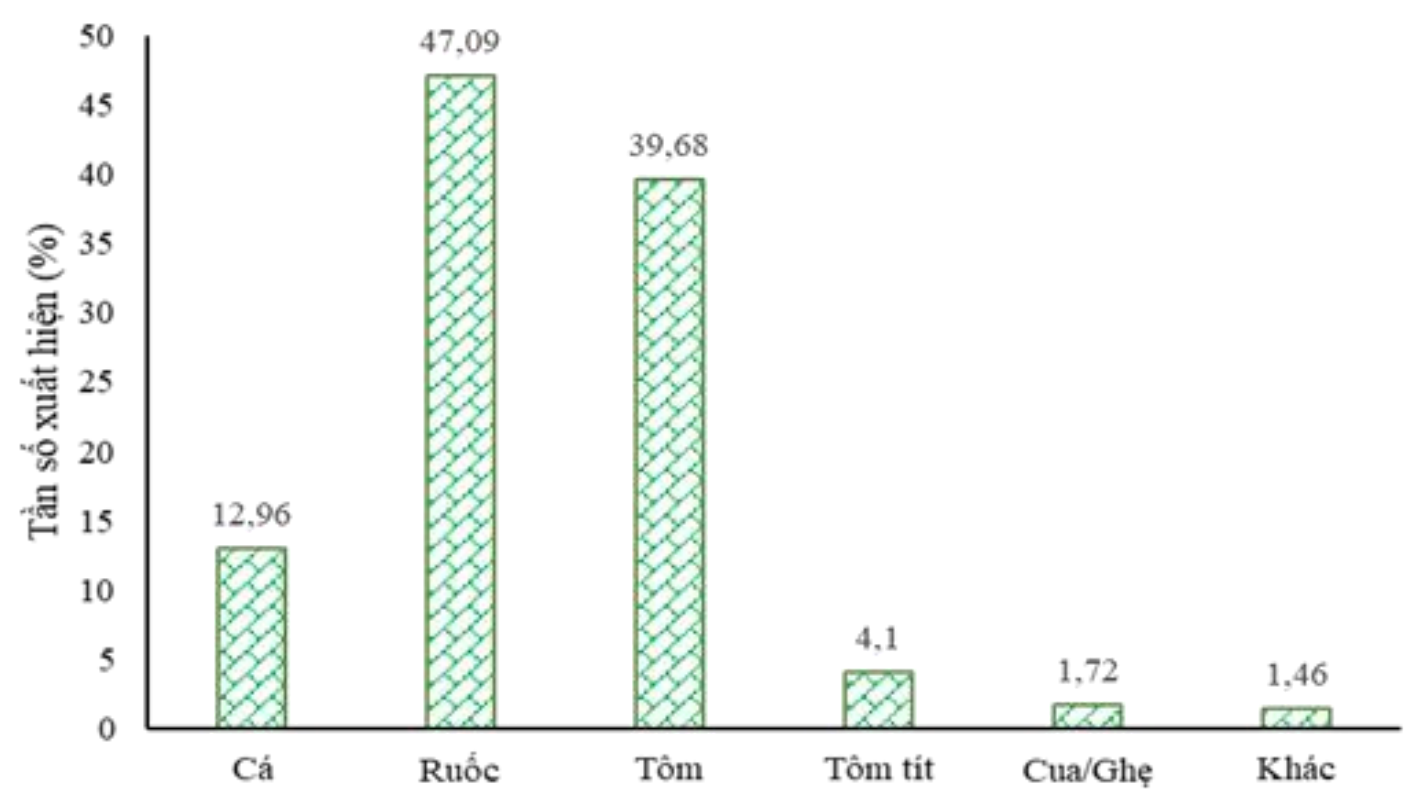

Hình 8. Tần suất xuất hiện các loại thức ăn 


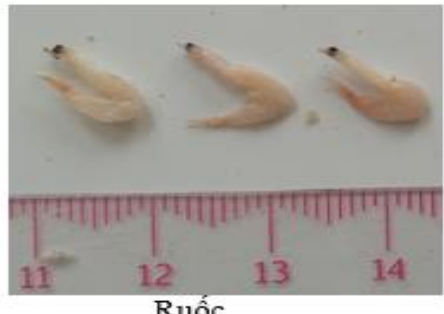

Ruốc

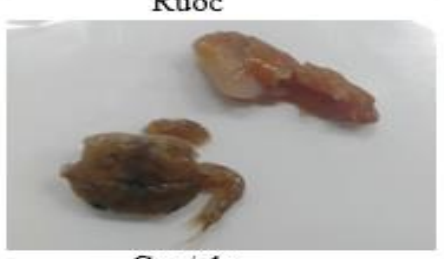

Cua/ghe

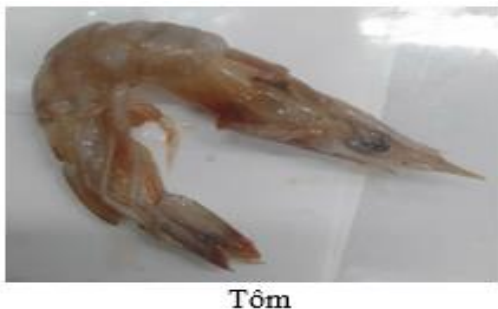

Tôm

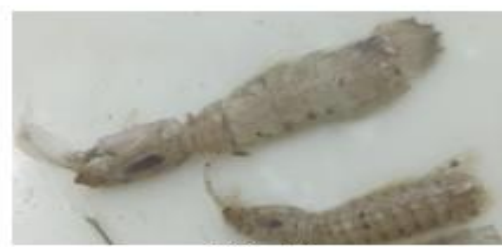

Tôm tít

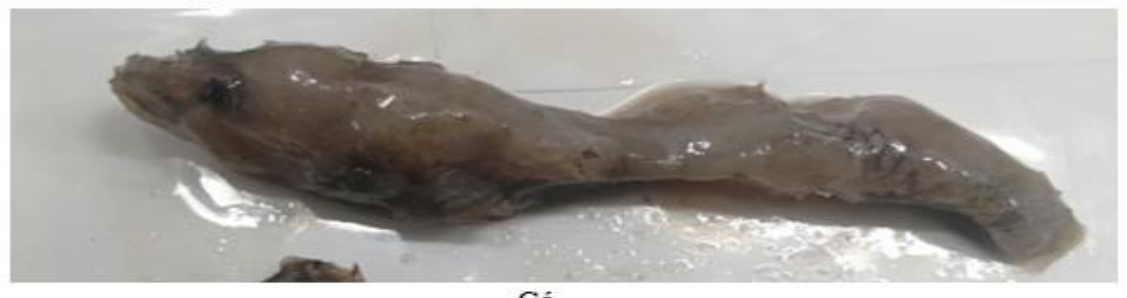

Cá

Hình 9. Các loại thức ăn của cá sửu răng nhỏ

Bảng 1. Thành phần thức ăn của cá sửu răng nhỏ

\begin{tabular}{|c|c|c|c|}
\hline Nhóm & Loại thức ăn & Số mẫu quan sát (N=756) & TSXH (\%) \\
\hline Cá & Cá & 98 & 12,96 \\
\hline \multirow{4}{*}{$\begin{array}{l}\text { Giáp } \\
\text { lớn }\end{array}$} & Ruốc & 356 & 47,09 \\
\hline & Tôm & 300 & 39,68 \\
\hline & Tôm tít & 31 & 4,1 \\
\hline & Cua/Ghẹ & 13 & 1,72 \\
\hline Khác & Khác & 11 & 1,46 \\
\hline
\end{tabular}

\subsubsection{Phuoong pháp khối lượng}

Tỉ lệ thành phần thức ăn trong dạ dày của cá sửu răng nhỏ tính theo phương pháp khối lượng được trình bày ở Bảng 2 . Kết quả cho thấy phần trăm khối Bảng 2. Thành phần thức ăn của cá sửu răng nhỏ theo phương pháp khối lượng

\begin{tabular}{llrr}
\hline Nhóm & Loại thức ăn & Khối lượng (g) & Khối lượng (\%) \\
\hline Cá & Cá & 0,9 & 43,48 \\
\hline \multirow{3}{*}{ Giáp xác } & Tôm & 0,33 & 15,94 \\
& Tôm tít & 0,43 & 20,77 \\
& Ruốc & 0,07 & 3,38 \\
& Cua/Ghẹ & 0,2 & 9,66 \\
\hline Khác & Khác & 0,14 & 6,76 \\
\hline Tồng & & 2,07 & 100 \\
\hline
\end{tabular}

\subsection{Phổ thức ăn}

Phổ thức ăn được xác định theo phương pháp tần số xuất hiện kết hợp với phương pháp khối lượng lượng của nhóm giáp xác chiếm tỉ lệ cao nhất $(49,75 \%)$, trong đó tôm $(15,94 \%)$, tôm tít $(20,77 \%)$, ruốc $(3,88 \%)$ và cua/ghẹ $(9,66 \%)$; kế đến là nhóm cá $(43,48 \%)$.

cho thấy phổ thức ăn của cá sửu răng nhỏ khá đa dạng; trong đó tôm chiếm tỉ lệ cao nhất $(43,1 \%)$, kế đến là cá $(38,4 \%)$, ruốc $(10,8 \%)$, tôm tít $(5,8 \%)$, cua/ghẹ $(1,2 \%)$ và các loại thức ăn khác $(0,7 \%)$. 


\section{Bảng 3. Phổ thức ăn của cá sửu răng nhỏ}

\begin{tabular}{lrrrr}
\hline Thức ăn & TSXH (\%) & Khối lượng (\%) & Tích số & Phổ thức ăn (\%) \\
\hline Tôm & 39,68 & 15,94 & 632 & 43,1 \\
Cá & 12,96 & 43,48 & 564 & 38,4 \\
Ruốc & 47,09 & 3,38 & 159 & 10,8 \\
Tôm tít & 4,1 & 20,77 & 85 & 5,8 \\
Cua/Ghẹ & 1,72 & 9,66 & 17 & 1,2 \\
Khác & 1,46 & 6,76 & 10 & 0,7 \\
\hline Tổng & & & 1.467 & 100 \\
\hline
\end{tabular}

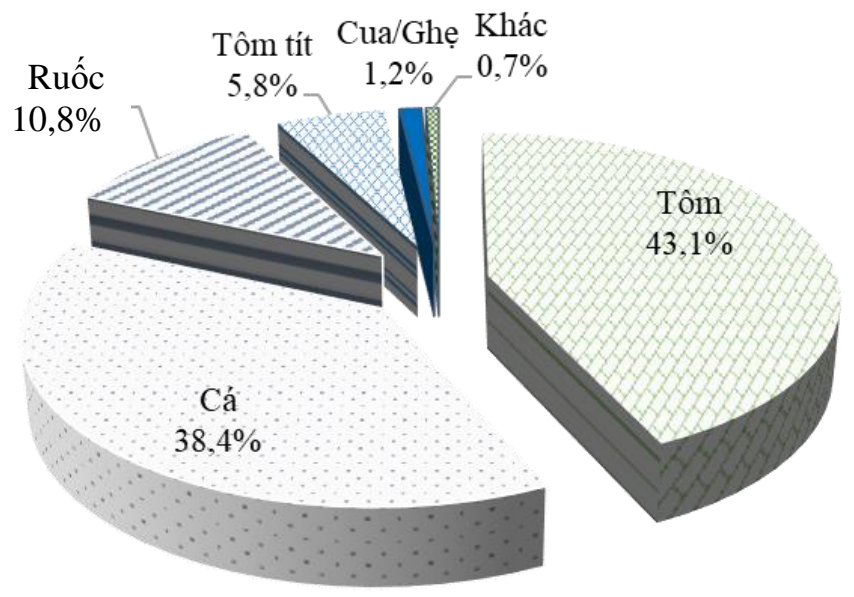

Hình 10. Phổ thức ăn của cá sửu răng nhỏ

So sánh với một số loài cá đù đã nghiên cứu trong và ngoài nước cho thấy thành phần thức ăn cũng như phổ thức ăn của cá sửu răng nhỏ trong nghiên cứu này khá đa dạng. Tuy nhiên so với nghiên cứu Mai Viết Văn (2017 \& 2020), nghiên cứu này chưa ghi nhận có xuất hiện giun nhiều tơ, mùn bã hữu cơ và mực cũng như so với Denadai
(2015) chưa ghi nhận có xuất hiện giun nhiều tơ và nhuyê̂n thể. Kết quả nghiên cứu có sự khác biệt này, nguyên nhân là do mỗi loài có tính ăn khác nhau cũng như khu vực phân bố. Ngoài ra, Chao \& Musick (1977) cho rằng các đặc điểm về ống tiêu hoá, manh tràng, và độ dài của ruột có thể là do thích nghi nhằm khai thác nguồn thức ăn hiệu quả.

Bảng 4. Một số kết quả nghiên cứu về phổ thức ăn của một số loài cá đù trong và ngoài nước

\begin{tabular}{cllll}
\hline $\begin{array}{c}\text { Phổ } \\
\text { thức ăn }\end{array}$ & $\begin{array}{l}\text { Mai Viết Văn } \\
(\mathbf{2 0 1 7})\end{array}$ & $\begin{array}{l}\text { Mai Viết Văn } \\
(\mathbf{2 0 2 0})\end{array}$ & Denadai (2015) & Nghiên cứu này \\
\hline Loài & Boesemania microlepis & Nibea soldado & Micropogonias furnieri & Panna microdon \\
\hline 1 & Cá con & Cá & Giáp xác & Cá \\
2 & Giáp xác & Cua & Giun nhiều tơ & Cua/ghẹ \\
3 & Giun nhiều tơ & Mực & Nhuyễn thể & Ruốc \\
4 & - & Mùn bã hữu cơ & - & Tôm \\
5 & - & Ruốc & - & Tôm tít \\
6 & - & Tôm & - & - \\
7 & - & Tôm tít & - & - \\
\hline
\end{tabular}

\section{KẾT LUẬn VÀ ĐỀ XUẤT}

\subsection{Kết luận}

Cá sửu răng nhỏ có miệng rộng, rạch miệng xiên, răng nhọn, lược mang thưa và ngắn, thực quản ngắn có vách dày, dạng hình ống, dạ dày hình túi với vách dày, manh tràng có từ 3 đến 8 ống, ruột ngắn và có dạng hình chữ $\mathrm{S}$. Chỉ số $\mathrm{RLG}<1$, cho thấy cá sửu răng nhỏ có tính ăn động vật.

Phổ thức ăn khá đa dạng với thành phần thức ăn chủ yếu trong dạ dày là cá, tôm, tôm tít, ruốc, cua/ghẹ và các loại thức ăn khác. 


\section{2. Đề xuất}

Cá sửu răng nhỏ là loài có giá trị kinh tế cao đặc biệt vùng ven biển ĐBSCL, do đó cần nghiên cứu thêm về tính ăn của cá sửu răng nhỏ ở các nhóm cá con và cá giống để có thông tin đầy đủ hơn về phổ thức ăn của loài cá này nhằm phục vụ cho công tác bảo tồn và quản lý nguồn lợi thủy sản.

\section{LỜI CẢM ƠN}

Đề tài này được tài trợ bởi Dự án Nâng cấp Trường Đại học Cần Thơ VN14-P6 bằng nguồn vốn vay ODA từ Chính phủ Nhật Bản.

\section{TÀI LIỆU THAM KHẢO}

Al-Hussainy, A.H. (1949). On the functional morphology of the alimentary tract of some fishes in relation to differences in their feeding habits. Quart.J. Micr. Sci., 9(2), 190-240.

Bond, C. E. (1996). Biology of Fishes. W. B. Saunder Co. Philadelphia.

Chao, L. N., \& Musick, J. A. (1977). Life-history, feeding-habits, and functional-morphology of juvenile Sciaenid fishes in York River Estuary, Virginia. Fishery Bulletin, 75(4), 657.

Denadai, M. R., Santos, F. B., Bessa, E., Fernandez, W. S., Luvisaro, C., \& Turra, A. (2015). Feeding habits of whitemouth croaker Micropogonias furnieri (Perciformes: Sciaenidae) in Caraguatatuba Bay, southeastern Brazil. Brazilian journal of oceanography, 63(2), 125-134.

FAO. (2001). The living marine resources of the Western central Pacific. Volume 5, Bony fishes part 3 (Menidae to Pomacentridae). Food and Agriculture Organization of the United nation Romes, 2001. 3117-3174 pages.

Froese, R. \& Pauly, D. (2021, May 3). Fishbase. http:// www.fishbase.org.

Lagler, K., Bardach, J.E., Miller, R.R. \& Passino, D.R.M. (1977). Ichthyology. New York: John Wiley \& Sons.

Mai Viết Văn, Trần Đắc Định \& Tojo, N. (2020). Đặc điểm dinh dưỡng của cá sửu Nibea soldado (Lacepède, 1802). Tạp chí khoa học Truờng Đại hoc Cần Tho, 56(1), 224-231.

Mai Viết Văn. (2017). Nghiên cứu tính ăn và phổ thức ăn của cá sửu Boesemania microlepis (Bleeker, 1858). Tạp chi khoa học Truòng Đại hoc Trà Vinh, 28, 82-88.
Mukherjee A., Mandal B., Marjumdar D. \& Bernejee S. (2012). Study on the distribution of Fin fish juveniles in few selected rivers of Indian Sundarbans. World Journal of Fish and Marine Sciences, 4(6), 554-565. DOI: 10.5829/idosi.wjfms.2012.04.06.6480.

Nguyễn Bạch Loan. (2004). Giáo trình Ngu loại I. Trường Đại học Cần Thơ. Trang 29-37.

Nguyễn Văn Thường \& Trương Quốc Phú (2009). Giáo trình Ngu loại II (Giáp xác và nhuyễn thể). Trường Đại học Cần Thơ.

Nikolsky, G.V. (1963). Ecology of fishes. Academic press, London.

Ocana-Luna, A. \& M. Sanchez-Ramirez. (1998). Feeding of Sciaenid (Pisces: Sciaenidae) Larvae in Two Coastal Lagoons of the Gulf of Mexico. Gulf Research Reports, 10(1), 1-9.

Phạm Thanh Liêm \& Trần Đắc Định (2004). Phuoong pháp nghiên cứu sinh học cá. Trường Đại học Cần Thơ.

Sasaki K. (1995). A review of the Indo-West Pacific sciaenid genus Panna (Telostei, Perciformes). Jap. J . Ichthyol. 42(1), 27-37.

Sasaki, K. (1989). Phylogeny of the family Sciaenidae, with notes on its zoogeograph (Teleostei, Perciformes). Meroirs of the faculty of fisheries Hokkaido University, 36(1-2), 97-98. http://hdl.handle.net/2115/21886.

Shirota, A. (1970). Studies on the mouth size of fish larvae. Bulletin of the Japanese Society of Scientific Fisheries, 36, 353-368.

Thong, N. B. (2008). Assessment of demersal fishery resources of the Southest and Southwest waters of Vietnam, based on bottom trawl survey in 2000-2005. Final project 2008. UNU-Fisheries Training Programme.

https://www.grocentre.is/static/gro/publication/2 9/document/thong08-prf.pdf.

Tôn Thất Chất \& Nguyễn Văn Chung (2013). Giáo trình ngu loại II (Phân loại giáp xác và động vật thân mềm). Nhà xuất bản Đại học Huế.

Trần Đắc Định, Shibukawa Koichi, Nguyễn Thanh Phương, Hà Phước Hùng, Trần Xuân Lợi, Mai Văn Hiếu \& Utsugi Kenzo. (2013). Mô tả định loại cá Đồng bằng sông Cửu Long, Việt Nam. Nhà xuất bản Đại học Cần Thơ. 